\title{
Bacterial Flora of the Anopheles fluviatilis S. L., the Vector of Malaria in Southern Iran for Proper Candidate Paratransgenesis
}

\author{
Jalal Mohammadi Soleimani ${ }^{1}$, Seyed Hassan Moosa-Kazemi ${ }^{1}{ }^{*}$, Hassan Vatandoost ${ }^{1}$, \\ Mohammad Hassan Shirazi ${ }^{2}$, Sara Hajikhani ${ }^{2}$, Roonak Bakhtiari ${ }^{2}$ and Siamak Hydarzade ${ }^{2}$ \\ ${ }^{1}$ Department of Medical Entomology and Vector Control, School of Public Health, \\ Tehran University of Medical Sciences, Tehran, Iran \\ ${ }^{2}$ Department of Pathobiology, School of Public Health, Tehran University of \\ Medical Sciences, Tehran, Iran \\ *Corresponding author
}

A B S T R A C T

Keywords

Anopheles

fluviatilis,

Microflora,

Bacteria, Malaria,

Paraterasgenesis,

Hormozgan,

Southern Iran.

Article Info

Accepted:

15 May 2017

Available Online:

10 June 2017
Malaria is considered most important health problems in the world. The disease was distributed in the south and southeast of Iran. At the present, Iran is in malaria elimination phase and new control tool need to vector control program. This study was carried out to find the bacteria for paraterasgenesis strategy as a new control method to cut the parasit life cycle. The microflora of the outer surface and gut of various stages of Anopheles fluviatilis James as one of the important malaria vector was studied using biochemical and molecular techniques during 2013-2014. Twelve bacteria species were found including; Providencia rettgeri, Morganella morganii, Enterobacter aerogenes, Pseudomonas oryzihabitans, Citrobacter braakii, Citrobacter freundii, Aeromonas hydrophila, Klebsiella oxytoca, Citrobacter koseri, Serratia fonticola, Enterobacter sakazakii and Yersinia pseudotuberculosis. The species of Alcaligenes faecalis, Providencia vermicola and Enterobacter hormaechei were identified in various stages of the vector and confirmed by biochemical and molecular techniques. It is found Providencia rettgeri proper candidate for paratransgenesis.

\section{Introduction}

Malaria is still is the important tropical diseases in the world. Malaria deaths were estimated 627000 worldwide in 2012. Based on last WHO report (2013), from 97 countries with ongoing malaria transmission, 12 are being in the preelimination phase, and 7 classified in the elimination phase (Organization,
2013). Based on Iranian Ministry of health report, $99 \%$ of malaria cases occur in Sistan and Baluchistan, Kerman and Hormozgan Provinces, Southeast of Iran. An estimated $33 \%$ of malaria cases were reported from Hormozgan, of whom 1450000 people were living in this area. Some socio-economic variables were increasing the number of 
malaria cases in Pakistan and Afghanistan and migration of malaria cases to Iran. At the present, at estimated more than 1 milion Afghans are registered as refugees in Iran(Organization, 2013).

The family Culicidae (Diptera) comprises at least 3531 species representing 112 genera divided into two subfamilies, Culicinae and Anophelinae (Harbach, 2013). According to the newest checklist of Iranian mosquitoes, 64 species representing seven genera occur in the country (Azari-Hamidian, 2007). Five Anopheles species was reported as the proven malaria vectors in southern Iran including; An stephensi, An fluviatilis, An culicifacies, An dthali, An superpictus and one as the suspected, An pulcherrimus (Nejati et al., 2013) Naddaf et al., (2010, 2012) reported the occurrences of the $A n$. fluviatilis James species $\mathrm{U}$ and $\mathrm{T}$ in Southern Iran (Naddaf et al., 2010; Naddaf et al., 2012). Two distinct peaks of malaria transmission occur in the southern Iran : one in April-May and the other in SeptemberOctober(Moosa-Kazemi et al., 2014). The peak of malaria incidence coincides with the peak vectors density of An. stephensi, as the main vectors, whereas An. fluviatilis plays a secondary role in the malaria transmission (Moosa-Kazemi et al., 2014). Indoor residual spraying (IRS) and distributed of long lasting impregnated bed nets are considered as the main strategy to control of malaria vectors in Iran during the malaria elimination phase (Nejati et al., 2013). IRS may reduced the population of endophile species of An. stephensi, whereas this control method has bit effects on the population of An fluviatilis with exophilic behavior (Moosa-Kazemi et al., 2007, Manouchehri et al., 1976).

There are scattered studies about the bacteria flora in the vectors in Iran. A study on aerobic bacterial flora of Periplaneta americana showed that 12 species found inside the gut of cockroaches and reported the Entrobacter cloacae as proper paratransgenesis candidate (Akbari et al., 2014). In the same study Chavshin et al., (2012) reported 12 genera, and 40 species bacterial microflora in the midgut of the larvae, and 5 genera and 25 species in the midget of the adult form of Anopheles stephensi wild strain. Pseudomonas sp. was reported as the proper paratransgenesis candidate (Chavshin et al., 2012). Only one research carried out on aerobic microbial community of sand fly Phlebotomus papatasi and the most prevalent isolates were Proteus mirabilis and $P$. vulgaris (Maleki-Ravasan et al., 2013). The new tools was introduced to vector control considered as; genetic manipulation of microorganisms symbionts of insect stomach and also recombinant of selected genes which are affecting, limiting and stopped the parasite life cycle (Chavshin et al., 2013). Paratransgenesis is new tool and original research to use it in an ongoing international research centers. One of the most basic and most important information for understanding paratransgenesis is identification of vectors gut microflora and sustainability status, location, and it is transferring situation of bacteria from larvae to adult stage.

Insect-borne microorganisms coexist in many aspects of life cycle such as nutrition, reproduction, resistance to environmental factors, maintaining and improving the immune system of the host, the protection strength of the mucosal barrier, metabolism, can play an important role in disease transmission.

Symbiont bacteria live in the mosquito stomach and may play an important role in development of the parasite, either enhance or inhibit it. In nature, mosquitoes feed on 
different types of materials and are suitable host to infected them. Such as bacteria, fungi may be destroyed the parasites (Gwadz et al., 1989; Lindh et al., 2005).

Typical vector control measures such as indoor residual spraying may be influence on vector resistance as well as the harmful effects on the environment, human health (Pimentel et al., 1992; Weill et al., 2003).

Larvae of An. fluviatilis was reported in beneath rocks along river beds, under the exposed roots of trees, in crevices artificial pits, edges of swamps, lake margins. In water currents and water will mix with the plants (Eshghi et al., 1976). Larvae was found in water and food that may be exposed to different types of microbes (Vatandoost et al., 2004; Rodrigues et al., 2010). Therefore, it is expected that the range of micro-organisms in the gut of larvae and pupae.

These microbes can be genetically engineered to express anti-parasite molecules and then again are added to larval habitats. This is a new method to control vector borne diseases is called paratransgenesis reducing pathogen transmission in an insect (Chavshin et al., 2013). This method introduced successfully for some vectors such Rhodnius prolixus vectors of Trypanosoma cruzi and vector of Chagas disease, Triatominae spp and also Glossina morsitans, vector of African sleeping sickness (Aksoy et al., 2008; Pontes and Dale, 2011).

This is a new method to control vector borne diseases is paratransgenesis, which could reduce or stop the pathogen transmission in a vector (Chavshin et al., 2013) .This method introduced successfully for some vectors such Rhodnius prolixus vectors of Trypanosoma cruzi and vector of Chagas disease (Beard et al., 2001), Triatominae spp and also Glossina morsitans, vector of African sleeping sickness(Aksoy et al., 2008, Pontes and Dale, 2011). High diversity of the intestinal bacterial microbiota was registered using culture dependent in relation to different populations of Phelebotomus argentipes and Lutzomyia longipalpis. Thus it is thought that the variation in the nutritional behavior of mosquitoes, as well as the conditions that they encounter in their growth stages Bacterial micro-flow is affected and the overall capacity it can also affect the preservation and development of the malaria parasite (Chavshin et al., 2012; Rajendran and Modi, 1981).

\section{Materials and Methods}

Area

This study was carried out in Hormozgan. In this area three villages Siahoo (E:56.13 $\mathrm{N}: 27.47)$, Hormodar (E:58.17 N:28.14), and Fein (E:51.55 N:37.27) were selected (Fig. 1). Standard dipping method as well as pyrethrum space spray collection carried out in selected villages

\section{Dissection}

Larvae, pupae and adult stages were collected in selected villages and samples were transferred to entomology laboratory and were dissected as follow; the outer surface of each biological stage was sterilized in $70 \%$ ethanol for 1minute. A drop of normal saline $(0.9 \%)$ was placed onto a glass slide mounted under the light microscope. A sample was transferred onto the prepared slide by stabbing the sample thorax with a needle-tip probe. While holding down the sample with the probe, the forceps were used to grasp the second to the last abdominal segment and gently pulled 
off the sample abdomen in a single motion. The midget was remained with the immobilized thorax. The abdomen is discarded and using the forceps the mid gut from the thorax was detached. Midgut was inserted in the media under the lab hood. Holly body without mid gut was inserted in the standard media in the same standard condition.

\section{Isolation of bacteria}

The bacterial microflora of larvae, pupae and adult An. fgluviatilis through biochemical techniques was carried out using diagnostic test kits, API 20E and BHI. Bacteria were isolated in the following way. An Inside gastric tubes containing $5 \mathrm{ml}$ of brain heart infusions (BHI) broth was placed on the vertex to homogeneous. Nonselective BHI broth was used as a culture medium for the growth of a wide range of microbes, especially bacteria. After 24 hours, samples were regarded as positive staining in BHI agar and again incubated overnight at $37^{\circ} \mathrm{C}$. To obtain a single colony of bacteria, colonies with different phenotypes were subcultured and single colonies were examined for identification.

\section{Identification of bacteria using biomedical test}

Gram staining was performed using standard kit to separate bacteria morphologically. In addition, agar medium MacConkey was used to distinct. Biochemical characteristics of gram-negative bacteria were identified using traditional identification Gallery kit plus API 20 E media supported by bio merieux, France. The single and new colony of bacteria suspended as equal to 2 McFarland and then injected to kit hollows.

The samples were incubated for 24 hours at $37^{\circ} \mathrm{C}$ and after adding the standard reagents such as Kovics in NID after 2 min, Band A Barritts in VP after 10 minutes, Fel3 to TDA after 1 minutes, then results were analyzed by kit soft ware and recorded. Based on API kit protocol, the ranges of colors of API were various and the results were discussed. Results were analysied using API soft ware as instruments described by Biomerieux Company. Bacteria were identified at the level of the genus and sometimes species.

\section{Identification of bacteria using molecular study}

Fresh simple colonies incubated overnight in liquid cultures in nutrient agar were used to Genomic DNA extraction. DNA was extracted by boiling techniques. For genotyping, a $1500 \mathrm{bp}$ of $16 \mathrm{~s}$ rRNA gene was amplified with specific primers as forward as 5'GAGTTTGATCTTGGCTCA 3' and Reverse as5' GTTACCTTGT TACGACTT3' that described by Weisburg protocol (Weisburg et al., 1991). Amplification was carried out on the isolates with the following PCR cycling conditions: an initial denaturation at $94^{\circ} \mathrm{C}$ for $10 \mathrm{~min}$, followed by 30 cycles of denaturation at $94^{\circ} \mathrm{C}$ for $30 \mathrm{~s}$, annealing at $56.5^{\circ} \mathrm{C}$ for $40 \mathrm{~s}$, and extension at $72^{\circ} \mathrm{C}$ for $40 \mathrm{~s}$, and final extension at $72^{\circ} \mathrm{C}$ for $10 \mathrm{~min}$ (Karimian et al., 2011).

\section{DNA sequencing}

The PCR products of the isolates were sequenced by Seqlab, Germany using the amplification primers. Consensus sequences obtained from forward and reverse sequences and their homologies with the available sequence data in GenBank were tested by using the basic local alignment search tool (BLASTn) alignment program and the NCBI nucleotide database NCBI (www.ncbi.nlm. nih.gov/BLAST). 
Single colonies of bacteria isolated from the outer surface and the gut of three biological stages of An. fluviatilis collected from Sistan and Baluchistan Province was shown in Table1. Of the 746 single colonies were isolated from $40 \%$ of the gut samples and $60 \%$ of the outer surface of the species. The number of gut colonies in Dashtook village was found to be $37 \%$ and the lowest $28 \%$ found in Uraky. Single colonies were growth on the outer surface, were found at least $24 \%$ in Uraky and maximum $42 \%$ in Dashtook Villages. Total single colony isolated from larvae, pupae and adults stages were found $79 \%, 12 \%$ and $9 \%$ respectively.

Table 2 was shown the biochemical reaction of API 20E kit of the bacteria were growth on the larvae, pupae and adults samples that were collected in three villages selected in Sistan-Baluchistan Province. This reaction was carried out after the exposure with 20 various sugars and amino acids.

In this reaction 12 species were identified including; Providencia rettger, Morganella morganii, Enterobacter aerogenes, Pseudomonas oryzihabitans, Citrobacter braakii, Citrobacter freundii, Aeromonas hydrophila, Klebsiella oxytoca, Citrobacter koseri, Serratia fonticola, Enterobacter sakazakii and Yersinia pseudotuberculosis.

Biochemical reaction of API 20E kit on bacteria was growth on the larvae, pupae and adults samples were collected in three villages selected in Hormozgan Province in 2013 (Table 2).

\section{Results and Discussion}

The result of the reaction of glucose and amino acids in bacteria samples, sometimes were various, so in this study the standard software for identification of the bacteria species was used. In addition, we found 12 species of bacteria from the gut and outer surface of An. fluviatilis and were recorded for the first time. We use non selective of BHI broth culture was used to improve the growth of a wide range of bacteria in the recent research. In this study the growth of almost all Gram-negative bacteria especially of the family of Enterobacteriaceae inside the BHI media.

The results of this study using the API $20 \mathrm{E}$ showed that gut and surface of An. fluviatilis have a diverse community of aerobic and Gram-negative bacteria of the Enterobacteriacea.

However, many of these bacteria are variable and their presents depend on the environment or food supplies in the Anopheles larval habitats. A few nontransient bacteria (possibly coexist) isolated of the gut and outer surface of An. fluviatilis and were identified, which, most of them were belonging to genera of Enterobacter and Citrobacter. Although a large number of bacteria were decreased during the metamorphosis from larvae to adult stages (Moll et al., 2001), only a small number of bacteria could transmission from larval to adult stages ( trans-stadia forms ).

Comparison of gut flora of larvae and adults showed that some Provedencia and Morganella species/strains occurrences in both stage the representative to trans-stadial condition. However, it is recommended that trans-stadial transmission of this species was examined using a phenotypic marker, such as a green fluorescent protein (GFP), which this method was used for Asaia bacteria previously (Favia et al., 2007). 
Table.1 Single colonies of bacteria isolated from the outer surface and the gut of Anopheles fluviatilis collected from Hormozgan Province, 2013

\begin{tabular}{|c|c|c|c|c|c|c|c|c|c|}
\hline \multirow{5}{*}{$\begin{array}{l}\text { Single gram- } \\
\text { negative } \\
\text { colonies from } \\
\text { Stomach } \\
\text { of Anopheles } \\
\text { fluviatilis }\end{array}$} & \multirow[t]{2}{*}{ Area } & \multicolumn{2}{|c|}{ Larvae } & \multicolumn{2}{|c|}{ Pupa } & \multicolumn{2}{|c|}{ Adult } & \multicolumn{2}{|l|}{ No } \\
\hline & & No & Percent & No & Percent & No & Percent & No & Percent \\
\hline & $\begin{array}{c}\text { Hormozgan Province } \\
\text { (Hormodar) }\end{array}$ & 78 & 50 & 38 & 24.5 & 38 & 25.5 & 154 & 45 \\
\hline & $\begin{array}{c}\text { Hormozgan } \\
\text { Province(Fein) }\end{array}$ & 37 & 40 & 30 & 32 & 26 & 28 & 93 & 27 \\
\hline & $\begin{array}{c}\text { Hormozgan } \\
\text { Province(Siaho) }\end{array}$ & 75 & 80 & 5 & 5 & 14 & 15 & 94 & 28 \\
\hline \multicolumn{2}{|r|}{ Total } & 190 & 56 & 73 & 21 & 78 & 23 & 341 & 100 \\
\hline \multirow{4}{*}{$\begin{array}{l}\text { Single Gram- } \\
\text { negative } \\
\text { colonies } \\
\text { from } \\
\text { Exterior of } \\
\text { Anopheles } \\
\text { fluviatilis }\end{array}$} & $\begin{array}{c}\text { Hormozgan } \\
\text { Province(Hormodar) }\end{array}$ & 263 & 82 & 33 & 10 & 25 & 8 & 321 & 57 \\
\hline & $\begin{array}{c}\text { Hormozgan } \\
\text { Province(Fein) }\end{array}$ & 49 & 46 & 30 & 28 & 28 & 26 & 107 & 19 \\
\hline & $\begin{array}{c}\text { Hormozgan } \\
\text { Province(Siaho) }\end{array}$ & 44 & 32 & 26 & 19 & 66 & 48 & 136 & 24 \\
\hline & Total & 356 & 63 & 89 & 16 & 119 & 21 & 564 & 100 \\
\hline \multicolumn{2}{|c|}{ Total single colonies } & 546 & 60 & 162 & 18 & 197 & 22 & 905 & 55 \\
\hline
\end{tabular}

Fig.1 Map of the study area, Hormozgan Province, Southern Iran

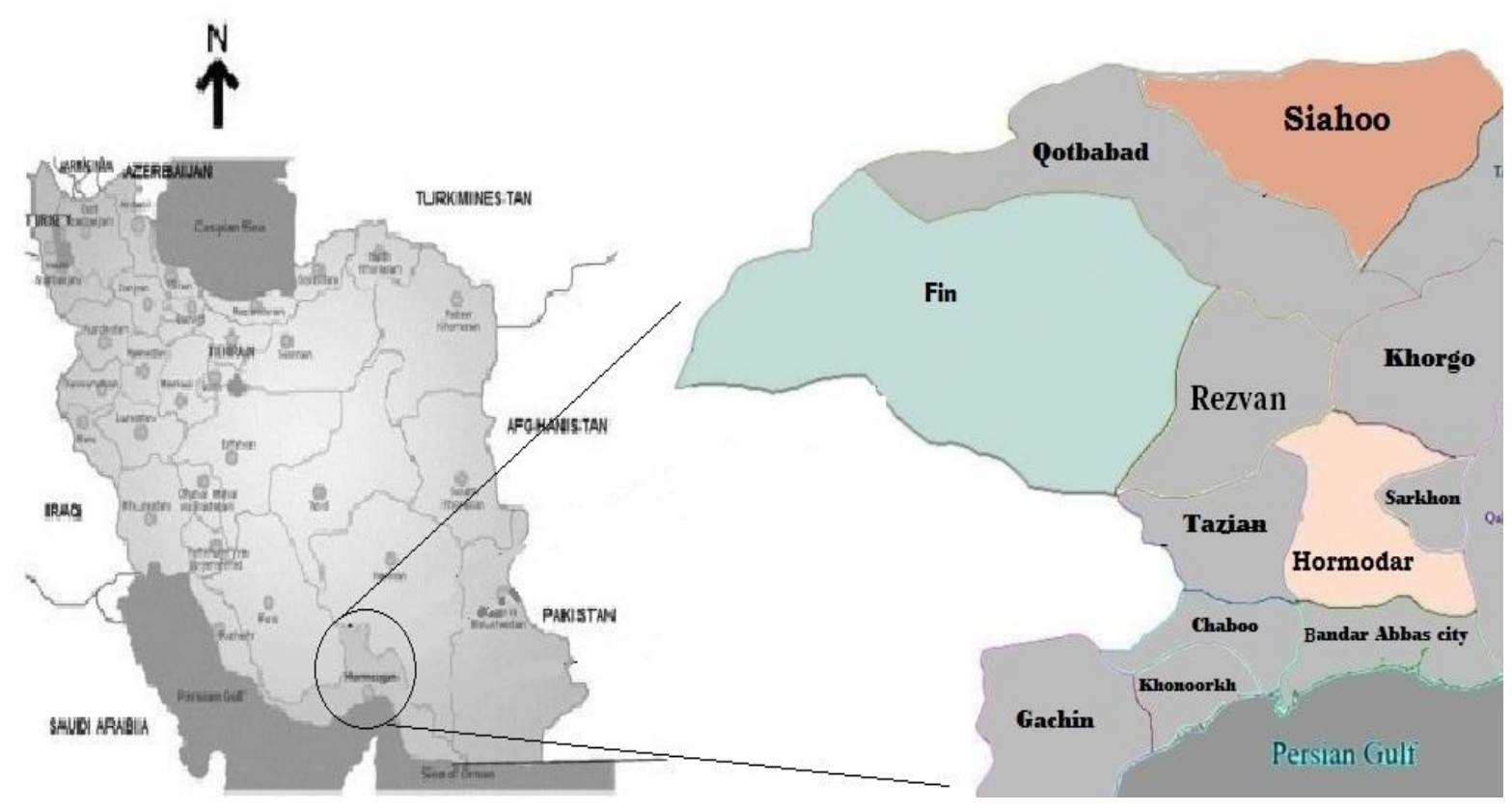


Table.2 Biochemical reaction of API 20E kit on bacteria were growth on the larvae, pupae and adults samples that were collected in three villages selected in Hormozgan Province, 2013

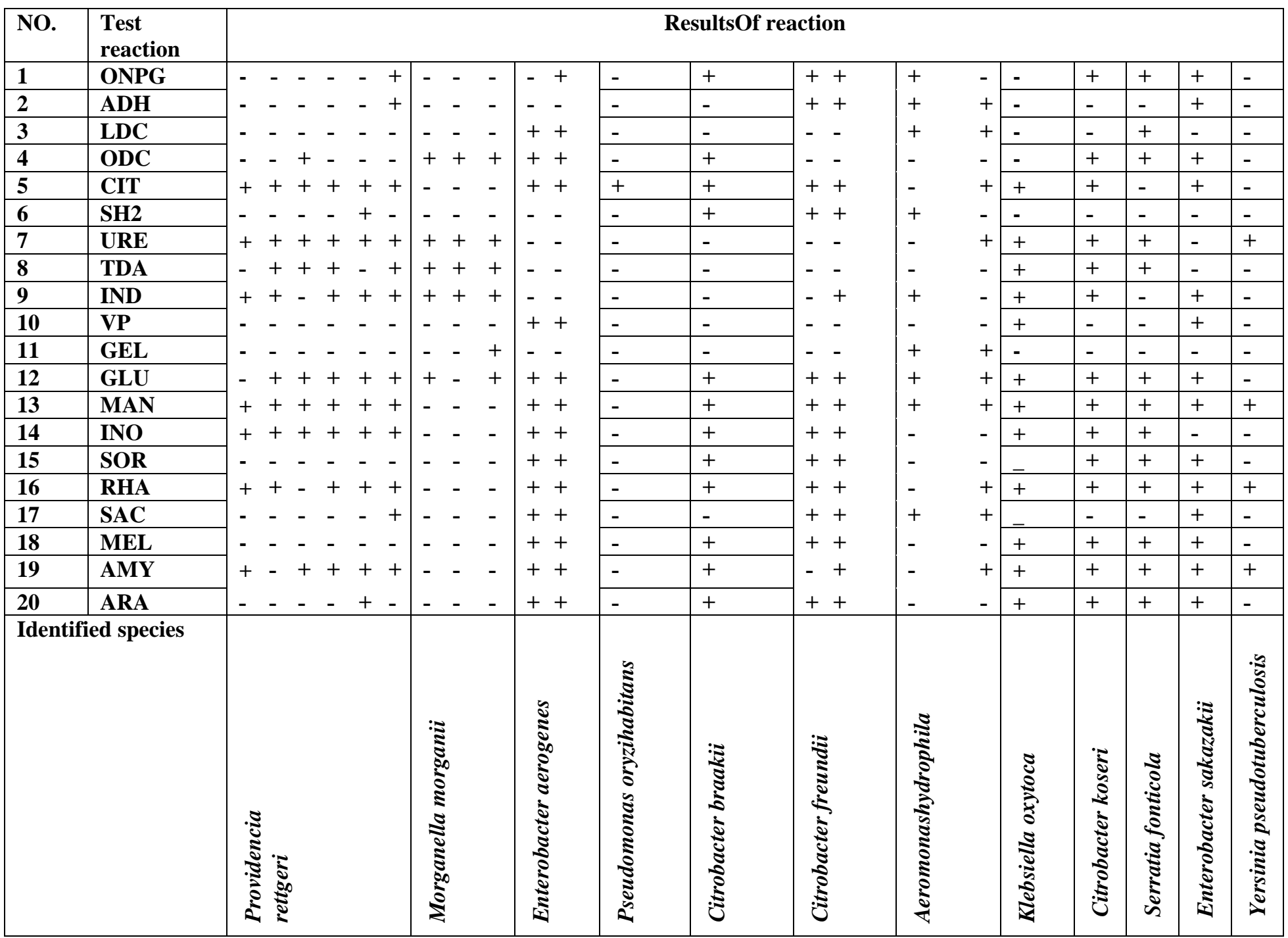

$\mathbf{O N P G}=$ ortho-nitrophenyl galactopyranosidase, $\mathbf{A D H}=$ arginine dihydrolase, $\mathbf{L D C}=$ lysine decarboxylase, $\mathbf{O D C}=$ ornithine decarboxylase, $\mathbf{C I T}=$ citrate, $\mathbf{U R E}=$ urease, $\mathbf{I N D}=$ indole, $\mathbf{V P}=$ Voges Proskauer, $\mathbf{G E L}=$ gelatinase, $\mathbf{G L U}=$ glucose, $\mathbf{M A N}=$ mannitol, $\mathbf{I N O}=$ inositol, $\mathbf{S O R}=$ sorbitol, $\mathbf{R H A}=$ rhamnose, $\mathbf{S A C}=$ saccharose $\mathbf{A M Y}=$ amygdalin, $\mathbf{A R A}=$ arabinose, $\mathbf{T D A}=$ tryptophan deaminase, $\mathbf{M E L}=$ melibiose 
Table.3 Isolated Bacteria of gut and outer surfaces of larvae, pupae, and adults stages of $A n$. fluviatilis S.L. and their closest relative according to Blast in based on $0.7-1.3 \mathrm{~kb}$ of $16 \mathrm{~s}$ rRNA gene, 2013

\begin{tabular}{|c|c|c|c|c|c|c|c|c|c|c|c|c|}
\hline \multirow{3}{*}{$\begin{array}{c}\text { Genera and species of } \\
\text { bacteria through } \\
\text { biochemical }\end{array}$} & \multicolumn{3}{|c|}{ Stomach } & \multicolumn{3}{|c|}{ outer surfaces } & \multirow{2}{*}{\multicolumn{3}{|c|}{ Topography }} & \multirow{3}{*}{$\begin{array}{l}\text { Genus and } \\
\text { species } \\
\text { Through } \\
\text { molecular }\end{array}$} & \multirow{3}{*}{$\begin{array}{l}\text { Code and percent } \\
\text { similarity of samples at } \\
\text { Software blast and } \\
\text { recorded in the gene bank }\end{array}$} & \multirow{3}{*}{$\sum_{[x]}^{\frac{\pi}{5}}$} \\
\hline & \multirow[b]{2}{*}{ 卷 } & \multirow[b]{2}{*}{ 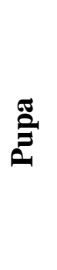 } & \multirow[b]{2}{*}{ 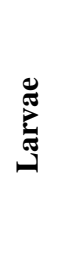 } & \multirow[b]{2}{*}{ 亚 } & \multirow[b]{2}{*}{ 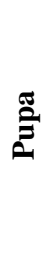 } & \multirow[b]{2}{*}{ 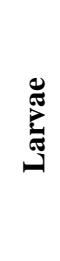 } & & & & & & \\
\hline & & & & & & & 䔍 & $\frac{\check{a}}{\varpi}$ & $\frac{\Xi}{a}$ & & & \\
\hline Providencia rettgeri & + & + & + & + & + & + & + & + & + & $\begin{array}{l}\text { Providencia } \\
\text { rettgeri }\end{array}$ & GU457413.1 (\%100) & 0.0 \\
\hline Morganella morganii & + & + & + & + & + & + & + & + & + & $\begin{array}{c}\text { Morganella } \\
\text { morganii }\end{array}$ & KJ794191.1 (\%100) & $\mathbf{0 . 0}$ \\
\hline $\begin{array}{c}\text { Enterobacter } \\
\text { aerogenes }\end{array}$ & + & - & + & - & + & + & - & + & - & $\begin{array}{c}\text { Enterobacter } \\
\text { aerogenes }\end{array}$ & KJ997976.1 (\%100) & 0.0 \\
\hline $\begin{array}{l}\text { Pseudomonas } \\
\text { oryzihabitans }\end{array}$ & + & - & + & - & + & + & - & + & + & $\begin{array}{c}\text { Alcaligenes } \\
\text { faecalis }\end{array}$ & KJ672381.1 (\%100) & 0.0 \\
\hline Citrobacter braakii & - & - & - & - & - & + & - & - & + & $\begin{array}{r}\text { Serratia } \\
\text { fonticola }\end{array}$ & JN596121.1(\%100) & $\mathbf{0 . 0}$ \\
\hline $\begin{array}{c}\text { Citrobacter } \\
\text { Freundii }\end{array}$ & - & - & - & + & - & + & - & + & - & $\begin{array}{c}\text { Citrobacter } \\
\text { freundii }\end{array}$ & KM269033.1 (\%100) & 0.0 \\
\hline Aeromonas hydrophila & - & - & + & - & - & - & - & - & + & $\begin{array}{l}\text { Aeromonas } \\
\text { hydrophila }\end{array}$ & KM362733.1 (\%100) & 0.0 \\
\hline $\begin{array}{c}\text { Klebsiella } \\
\text { Oxytoca }\end{array}$ & - & + & - & - & + & - & - & + & - & $\begin{array}{c}\text { Providencia } \\
\text { rettger }\end{array}$ & KF534469.1 (\%100) & 0.0 \\
\hline $\begin{array}{c}\text { Citrobacter } \\
\text { koseri/amalonaticus }\end{array}$ & - & - & + & + & - & - & + & - & + & $\begin{array}{l}\text { Providencia } \\
\text { vermicola }\end{array}$ & KJ909024.1 (\%99) & 0.0 \\
\hline Serratia fonticola & - & + & - & - & - & + & + & + & - & $\begin{array}{c}\text { Morganella } \\
\text { morganii }\end{array}$ & LN558632.1(\%100) & $\mathbf{0 . 0}$ \\
\hline $\begin{array}{c}\text { Enterobacter } \\
\text { Sakazakii }\end{array}$ & - & - & - & - & - & + & - & - & + & $\begin{array}{c}\text { Enterobacter } \\
\text { hormaechei }\end{array}$ & KJ628424.1(\%99) & 0.0 \\
\hline $\begin{array}{c}\text { Yersinia } \\
\text { pseudotuberculosis }\end{array}$ & + & + & + & - & - & + & + & + & - & $\begin{array}{l}\text { Providencia } \\
\text { rettgeri }\end{array}$ & GU457413.1 (\%98) & 0.0 \\
\hline
\end{tabular}

Adult mosquitoes were targeted for paratransgenesis method (Lindh et al., 2008). Trans-stadial characters were found among the bacteria in both Gram-negative and gram-positive (Wirth et al., 1989). Load of the malaria parasite in infected mosquitoes by bacteria were reduced the prevalence of the Plasmodium falciparum and $P$. vivax (Gonzalez-Ceron et al., 2003, Pumpuni et al., 1996). In another study Gram-negative bacteria of the general of
"Enterobacter" affect on $P$. falciparum (Cirimotich et al., 2011).

In conclusion, It should be noted that, the wide range of the bacterial growth on the selective media and could be used for paratransgenesis and control of malaria in the future. Selected medium such as BHI, could be used to promote the growth of gram-negative bacteria, especially bacteria in the family Enterobacteriaceae. Simbiont 
bacteria live in the mosquito gut and outer surface and could play an important role in development of the parasite, and the other hand cut the parasite life cycle. We were found Providencia rettgeri, Morganella morganelli, and Yersinia psudotuberculosis in biologic stages of An. fluviatilis s.l. which confirmed by biochemical and molecular techniques. We suggested Providencia rettgeri proper candidate for paratransgenesis.

\section{Acknowledgments}

We thank M. Dorzadeh in Saravan, Parvin in Nikshahr, and Raeisi in Chabahar Counties for assistance in sampling methods, Dr Mirhendi, Dr Zahraei, Mrs Hashemi for helping us with the molecular assays. The authors thank to Dr Holaquei, Dr Nategpour head of Bandar Abbas and Iranshahr health training and research centers for help us during research. Some of mosquito larvae and adult sample were mounted and deposited in Zoology and Medical Entomology Museum in School of Public Health, TUMS and recorded as the code No.GC22ST8-93.This project was financially supported by TUMS as code No 93-03-2726587.

\section{References}

Akbari, S., Oshaghi, M.A., HashemiAghdam, S.S., Hajikhani, S., Oshaghi, G. and Shirazi, M. H. 2014. Aerobic bacterial community of American cockroach Periplaneta americana, a step toward finding suitable paratransgenesis candidates. Journal of Arthropod-Borne Diseases.

Aksoy, S., Weiss, B. and Attardo, G. 2008. Paratransgenesis applied for control of tsetse transmitted sleeping sickness. Transgenesis and the
Management of Vector-Borne Disease. Springer.

Azari-Hamidian, S. 2007. Checklist of Iranian mosquitoes (Diptera: Culicidae). Journal of Vector Ecology, 32, 235-242.

Beard, C., Dotson, E., Pennington, P., Eichler, s., Cordon-rosales, C. and Durvasula, R. 2001. Bacterial symbiosis and paratransgenic control of vector-borne Chagas disease. International journal for parasitology, 31, 621-627.

Chavshin, A. R., Oshaghi, M. A., Vatandoost, H., Pourmand, M. R., Raeisi, A., Enayati, A. A., Mardani, N. and Ghoorchian, S. 2012. Identification of bacterial microflora in the midgut of the larvae and adult of wild caught Anopheles stephensi: A step toward finding suitable paratransgenesis candidates. Acta tropica, 121, 129-134.

Chavshin, A. R., Oshaghi, M. A., Vatandoost, H., Yakhchali, B., Raeisi, A. and Zarenejad, F. 2013. Escherichia coli expressing a green fluorescent protein (GFP) in Anopheles stephensi: a preliminary model for paratransgenesis. Symbiosis, 60, 17-24.

Cirimotich, C. M., Dong, Y., Clayton, A. M., Sandiford, S. L., Souza-Neto, J. A., Mulenga, M. and Dimopoulos, G. 2011. Natural microbe-mediated refractoriness to Plasmodium infection in Anopheles gambiae. Science, 332, 855-858.

Eshghi, N., Motabar, M., Javadian, E. and Manoutcheri, A. 1976. Biological features of Anopheles fluviatilis and its role in the transmission of malaria in IRAN.

Favia, G., Ricci, I., Damiani, C., Raddadi, N., Crotti, E., Marzorati, M., Rizzi, A., Urso, R., Brusetti, L. and 
BORIN, S. 2007. Bacteria of the genus Asaia stably associate with Anopheles stephensi, an Asian malarial mosquito vector. Proceedings of the National Academy of Sciences, 104, 90479051.

Gonzalez-Ceron, L., Santillan, F., Rodriguez, M. H., Mendez, D. and Hernandez-Avila, J. E. 2003. Bacteria in midguts of field-collected Anopheles albimanus block Plasmodium vivax sporogonic development. Journal of medical entomology, 40, 371-374.

Gwadz, R., Kaslow, D., Lee, J.-Y., Maloy, W., Zasloff, M. and Miller, L. 1989. Effects of magainins and cecropins on the sporogonic development of malaria parasites in mosquitoes. Infection and immunity, 57, 26282633.

Harbach, R. 2013. Anopheles Classification: Mosquito Taxonomic Inventory.

Karimian, F., Sedaghat, M., Oshaghi, M., Mohtarami, F., Dehkordi, A. S., Koosha, M., Akbari, S. and Hashemi-Aghdam, S. 2011. Utility of filter paper for preserving insects, bacteria, and host reservoir DNA for molecular testing. Iranian journal of arthropod-borne diseases, 5, 42.

Lindh, J., Borg-Karlson, A.-K. and Faye, I. 2008. Transstadial and horizontal transfer of bacteria within a colony of Anopheles gambiae (Diptera: Culicidae) and oviposition response to bacteria-containing water. Acta tropica, 107, 242-250.

Lindh, J. M., Terenius, O. and Faye, I. 2005. 16S rRNA gene-based identification of midgut bacteria from field-caught Anopheles gambiae sensu lato and $A$. funestus mosquitoes reveals new species related to known insect symbionts. Applied and environmental microbiology, 71, 7217-7223.

Maleki-Ravasan, N., Oshaghi, M. A., Hajikhani, S., Saeidi, Z., Akhavan, A. A., Gerami-Shoar, M., Shirazi, M. H., Yakhchali, B., Rassi, Y. and Afshar, D. 2013. Aerobic microbial community of insectary population of Phlebotomus papatasi. Journal of Arthropod-Borne Diseases, 8, 69.

Manouchehri, A., Djanbakhsh, B. and Eshghi, N. 1976. The biting cycle of Anopheles dthali. A. fluviatilis and A. stephensi in southern Iran. Tropical and geographical medicine, 28, 224227.

Moll, R. M., Romoser, W. S., Modrakowski, M. C., Moncayo, A. C. and Lerdthusnee, K. 2001. Meconial peritrophic membranes and the fate of midgut bacteria during mosquito (Diptera: Culicidae) metamorphosis. Journal of medical entomology, 38, 29-32.

Moosa-Kazemi, S., Vatandoost, H., Raeisi, A. and Akbarzadeh, K. 2007. Deltamethrin impregnated bed nets in a malaria control program in Chabahar, Southeast Baluchistan, IR Iran. Journal of Arthropod-Borne Diseases, 1, 43-51.

Moosa-Kazemi, S. H., Zahirnia, A. H., Sharifi, F. and Davari, B. 2014. The Fauna and Ecology of Mosquitoes (Diptera: Culicidae) in Western Iran. Journal of Arthropod-Borne Diseases.

Naddaf, S. R., Oshaghi, M. A. and Vatandoost, H. 2012. Confirmation of two sibling species among Anopheles fluviatilis mosquitoes in south and southeastern Iran by analysis of cytochrome oxidase I Gene. Journal of arthropod-borne diseases, 6, 144. 
Naddaf, S. R., Razavi, M. R. and Bahramali, G. 2010. Molecular variation and distribution of Anopheles fluviatilis (Diptera: Culicidae) complex in Iran. The Korean journal of parasitology, 48, 231-236.

Nejati, J., Vatandoost, H., Oshghi, M. A., Salehi, M., Mozafari, E. and MoosaKazemi, S. H. 2013. Some ecological attributes of malarial vector Anopheles superpictus Grassi in endemic foci in southeastern Iran. Asian Pacific journal of tropical biomedicine, 3, 1003-1008.

Organization, W. H. 2013. Malaria entomology and vector control, World Health Organization.

Pimentel, D., Acquay, H., Biltonen, M., Rice, P., Silva, M., Nelson, J., Lipner, V., Giordano, S., Horowitz, A. and D'amore, M. 1992. Environmental and economic costs of pesticide use. BioScience, 750760.

Pontes, M. H. and Dale, C. 2011. Lambda Red-mediated genetic modification of the insect endosymbiont Sodalis glossinidius. Applied and environmental microbiology, 77, 1918-1920.

Pumpuni, C. B., Demaio, J., Kent, M., Davis, J. R. and Beier, J. C. 1996. Bacterial population dynamics in three anopheline species: the impact on Plasmodium sporogonic development. The American journal of tropical medicine and hygiene, 54, 214-218.

\section{How to cite this article:}

Jalal Mohammadi Soleimani, Seyed Hassan Moosa-Kazemi, Hassan Vatandoost, Mohammad Hassan Shirazi, Sara Hajikhani, Roonak Bakhtiari and Siamak Hydarzade. 2017. Bacterial Flora of the Anopheles fluviatilis S. L., the Vector of Malaria in Southern Iran for Proper Candidate Paratransgenesis. Int.J.Curr.Microbiol.App.Sci. 6(6): 3275-3285. doi: https://doi.org/10.20546/ijcmas.2017.606.385
Rajendran, P. and Modi, G. 1981. Bacterial flora of Sandfly gut (Diptera: Psychodidae). Indian journal of public health, 26, 49-52.

Rodrigues, J., Brayner, F. A., Alves, L. C., Dixit, R. and Barillas-Mury, C. 2010. Hemocyte differentiation mediates innate immune memory in Anopheles gambiae mosquitoes. Science, 329, 1353-1355.

Vatandoost, H., Shahi, H., Abai, M., HanafiBojd, A., Oshaghi, M. and Zamani, G. 2004. Larval habitats of main malaria vectors in Hormozgan province and their susceptibility to different larvicides. Southeast Asian J Trop Med Public Health, 35, 2225.

Weill, M., Lutfalla, G., Mogensen, K., Chandre, F., Berthomieu, A., Berticat, C., Pasteur, N., Philips, A., Fort, P. and Raymond, M. 2003. Comparative genomics: Insecticide resistance in mosquito vectors. Nature, 423, 136-137.

Weisburg, W. G., Barns, S. M., Pelletier, D. A. and Lane, D. J. 1991. 16S ribosomal DNA amplification for phylogenetic study. Journal of bacteriology, 173, 697-703.

Wirth, R., Friesenegger, A. and Fiedler, S. 1989. Transformation of various species of gram-negative bacteria belonging to 11 different genera by electroporation. Molecular and General Genetics MGG, 216, 175177. 